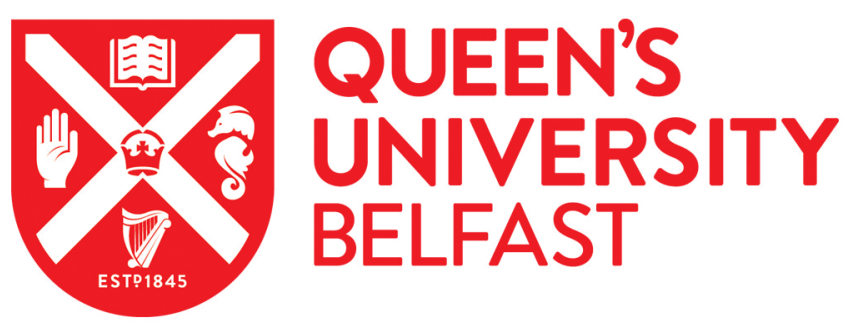

\title{
Structure Selectivity of Supported Pd nanoparticles for Catalytic NH3 Oxidation resolved using combined Operando Spectroscopy
}

Dann, E., Gibson, E., Blackmore, R., Catlow, R., Collier, P., Chutia, A., Eralp Erden, T., Hardacre, C., Kroner, A., Nachtegaal, M., Raj, A., Rogers, S., Taylor, R., Thompson, P., Tierney, G., Zeinalipour-Yazdi, C., Goguet, A., \& Wells, P. (2019). Structure Selectivity of Supported Pd nanoparticles for Catalytic NH3 Oxidation resolved using combined Operando Spectroscopy. Nature Catalysis, 2, 157-163. https://doi.org/10.1038/s41929-018-0213-3

Published in:

Nature Catalysis

Document Version:

Peer reviewed version

Queen's University Belfast - Research Portal:

Link to publication record in Queen's University Belfast Research Portal

Publisher rights

Copyright 2019 Nature Research. This work is made available online in accordance with the publisher's policies. Please refer to any applicable terms of use of the publisher.

\section{General rights}

Copyright for the publications made accessible via the Queen's University Belfast Research Portal is retained by the author(s) and / or other copyright owners and it is a condition of accessing these publications that users recognise and abide by the legal requirements associated with these rights.

Take down policy

The Research Portal is Queen's institutional repository that provides access to Queen's research output. Every effort has been made to ensure that content in the Research Portal does not infringe any person's rights, or applicable UK laws. If you discover content in the Research Portal that you believe breaches copyright or violates any law, please contact openaccess@qub.ac.uk. 


\title{
Structure Selectivity of Supported Pd nanoparticles for Catalytic $\mathrm{NH}_{3}$ Oxidation resolved using combined Operando Spectroscopy
}

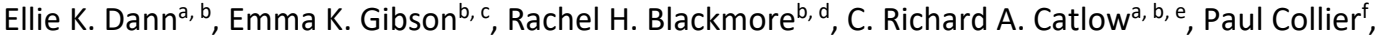 \\ Arunabhiram Chutiab, g, Tugce Eralp Erden ${ }^{f}$, Christopher Hardacre ${ }^{b}, h$, Anna Kroneri, Maarten Nachtegaali, Agnes \\ Raj $^{f}$, Scott M. Rogers ${ }^{a, b}$, S. F. Rebecca Taylor ${ }^{h}$, Paul Thompson ${ }^{k}$, George F. Tierney ${ }^{b, d}$, Constantinos D. \\ Zeinalipour-Yazdi ${ }^{b,}$, Alexandre Goguet ${ }^{b, m} *$ and Peter P. Wells ${ }^{b, d, i}$ *
}

a Department of Chemistry, University College London, 20 Gordon Street, London WC1H 0AJ

${ }^{b}$ UK Catalysis Hub, Research Complex at Harwell, Rutherford Appleton Laboratory, Oxfordshire, OX11 OFA, United Kingdom

' School of Chemistry, University of Glasgow, Joseph Black Building, University Avenue, Glasgow, G12 8QQ, United Kingdom

${ }^{d}$ University of Southampton School of Chemistry, University Road, Southampton, SO17 1BJ, United Kingdom

${ }^{\text {e } C a r d i f f}$ Catalysis Institute, School of Chemistry, Cardiff University, Main Building, Park Place, Cardiff, CF10 3AT, United Kingdom

f Johnson Matthey Technology Centre, Blounts Court Road, Sonning Common, Reading, RG4 9NH, United Kingdom

${ }^{g}$ College of Science, University of Lincoln, Brayford Pool Campus, Lincoln, LN6 7TS, United Kingdom

h School of Chemistry, The University of Manchester, Oxford Road, Manchester, M13 9PL, United Kingdom

' Diamond Light Source Ltd., Harwell Science and Innovation Campus, Chilton, Didcot OX11 0DE, United Kingdom

j Paul Scherrer Institute, WLGA/ 219, 5232 Villigen - PSI, Switzerland

${ }^{k}$ XMaS - UK CRG Beamline, ESRF - The European Synchrotron, 71, avenue des Martyrs, 38000 Grenoble, France.

'School of Science, University of Greenwich, Central Avenue, Chatham Maritime, Kent ME4 4TB, UK

m Queen's University Belfast School of Chemistry, David Keir Building, Stranmillis Rd, Belfast BT9 5AG, United Kingdom.

The selective catalytic oxidation of $\mathrm{NH}_{3}$ to $\mathrm{N}_{2}\left(\mathrm{NH}_{3}-\mathrm{SCO}\right)$ presents a promising solution for abatement of unused $\mathrm{NH}_{3}$-based reductants from diesel exhaust after treatment systems. Supported Pd nanoparticle catalysts show selectivity to $\mathrm{N}_{2}$, rather than $\mathrm{NO}_{x}$, which is investigated in this work. The link between Pd nanoparticle structure and surface reactivity is found by operando X-ray absorption Fine Structure (XAFS) spectroscopy, diffuse reflectance infrared Fourier transformed spectroscopy (DRIFTS) and on-line mass spectrometry. Nitrogen insertion into the metallic Pd nanoparticle structure at low temperatures $\left(<200^{\circ} \mathrm{C}\right)$ is found to be responsible for high $\mathrm{N}_{2}$ selectivity; whereas the unfavourable formation of NO is linked to adsorbed nitrates which form at the surface of bulk PdO nanoparticles at high temperatures $\left(>280^{\circ} \mathrm{C}\right)$. Our work demonstrates the ability for combined operando spectroscopy and DFT calculations to characterise a previously unidentified $\mathrm{PdN}_{\mathrm{x}}$ catalyst, and clarify the selectivity directing structure of supported Pd catalysts for $\mathrm{NH}_{3}-\mathrm{SCO}$.

The selective catalytic oxidation of ammonia $\left(\mathrm{NH}_{3}-\mathrm{SCO}\right)$ is needed to eliminate the slip of unreacted $\mathrm{NH}_{3}$ from automotive exhaust. $\mathrm{NH}_{3}$ is used as the reductant for the selective catalytic reduction $\left(\mathrm{NH}_{3} \mathrm{SCR}\right)$ of harmful nitrogen oxides $\left(\mathrm{NO}_{x}\right)$ that are released from diesel engines. $\mathrm{NH}_{3}$ slip from these exhaust systems is increasing as legislation pushes for greater efficiency of de-NO ${ }_{x}$ technology, which is achieved using greater amounts of the $\mathrm{NH}_{3}$ reductant. High performance catalysts for the $\mathrm{NH}_{3}-$ SCO reaction downstream of the $\mathrm{NH}_{3}-\mathrm{SCR}$ must be able to achieve complete conversion of $\mathrm{NH}_{3}$ to $\mathrm{N}_{2}$ and $\mathrm{H}_{2} \mathrm{O}$, at low temperatures $\left(T<400^{\circ} \mathrm{C}\right)$ and without the reformation of harmful $\mathrm{NO}_{x}$

Noble metals supported on metal oxides have repeatedly been found to possess high catalytic activity for $\mathrm{NH}_{3}$ oxidation at low temperatures, but over oxidation to nitrogen oxides is problematic. ${ }^{1-7}$ Various attempts to improve selectivity and avoid the use of noble metals have investigated the use of base metal oxides and transition metal ion exchanged zeolites. ${ }^{8-10}$ However, even the more selective of these catalysts, $\mathrm{CuO}_{1},{ }^{11,12}$ and $\mathrm{V}_{2} \mathrm{O}_{5},{ }^{13}$ have lacked sufficient activity to be of practical use.${ }^{14}$ Of all the noble metals, the most promising $\mathrm{N}_{2}$ selectivity is found for $\mathrm{Pd}$ based catalysts. ${ }^{15}$ Various studies with $\mathrm{Pd}$ catalysts have examined incorporation of $\mathrm{Pd}$ into multicomponent metal systems, ${ }^{3,16}$ mixed metal oxide perovskite materials ${ }^{17}$, the use of various supports ${ }^{18}$ and varying metal loading ${ }^{19}$, concluding that Pd nanoparticles (NPs) are the active species irrespective of the support. 19,20 Despite these studies, there remains little understanding of the fundamental chemistry that governs the catalytic activity of Pd NPs for $\mathrm{NH}_{3}-\mathrm{SCO}$.

The use of Pd NPs in catalysis is well established and it is accepted that Pd NP structure can change under different reaction environments. For example, the bulk oxidation and reduction of $\mathrm{Pd}$ NPs is demonstrated by switching the oxygen/fuel ratio during lean/rich methane oxidation. ${ }^{21}$ The formation of palladium hydrides and carbides is also reported during operation of hydrogenation reactions, which are found to affect the catalytic performance. ${ }^{22-24}$ However there is a lack of evidence regarding the noble metal structure and speciation for the $\mathrm{NH}_{3}-\mathrm{SCO}$ reaction. Zhang et al. have suggested that the oxidation state of the precious metal catalyst influences the $\mathrm{NH}_{3}$ SCO activity, but without in situ measurements it is difficult to draw definite conclusions. ${ }^{25}$ Furthermore, there is no explanation for the increasing formation of nitrogen oxides at higher temperatures..$^{20}$

These problems highlight the importance of in situ methods in studying the catalyst under real working environments. The high energy of the Pd K-edge (24357 eV), is advantageous for in situ and operando $\mathrm{X}$-ray absorption fine structure (XAFS) spectroscopy, which is able to penetrate the reaction medium and probe the $1 \mathrm{~s}$ to $4 \mathrm{p}$ electronic transitions of $\mathrm{Pd}$ atoms in the supported NP catalysts. X-rays at the $\mathrm{Pd} \mathrm{L}_{3}$-edge $(3173 \mathrm{eV})$ have lower penetrating power, but can also be used under carefully controlled in situ conditions to probe the $2 p$ to $d$ electronic transitions, giving information regarding the empty $d$ density of states which is crucial for distinguishing between hydride, carbide and other potential phases. ${ }^{26}$ Diffuse reflectance infrared Fourier transform spectroscopy (DRIFTS) may also be applied as a complementary in situ method, to provide information for the reaction mechanism by probing molecular vibrations of adsorbed intermediates at the catalyst surface.

In this study two high performance supported Pd NP catalysts $\left(\mathrm{Pd} / \mathrm{Y}-\mathrm{Al}_{2} \mathrm{O}_{3}\right.$ and $\mathrm{Pd} /$ zeolite- $\left.\mathrm{Y}\right)$ are investigated for $\mathrm{NH}_{3}-\mathrm{SCO}$ using a combination of XAFS with DRIFTS and on-line mass spectrometry (MS). By performing simultaneous XAFS and 
DRIFTS spectroscopy of the catalyst under operating conditions, links between bulk nanoparticle structure, reaction mechanisms and catalytic activity are revealed, which are also supported by our theoretical calculations based on density functional theory and dispersion corrections (DFT+D3). In this way, not only have we identified the Pd structural changes and formation of a previously unidentified $\mathrm{Pd}$ nitride that occur within the temperature range for $\mathrm{NH}_{3}-\mathrm{SCO}$; but we can also correlate these with the change in surface speciation, catalytic reactivity and product distribution.

\section{Results}

Ex situ characterisation Two supported $1.5 \mathrm{wt} \% \mathrm{Pd}$ catalysts were prepared by incipient wetness impregnation. Pd K-edge XANES of the supported Pd catalysts after impregnation and calcination were consistent with that of bulk PdO (Supplementary Figure 1). Transmission electron microscopy (TEM) images of the as prepared catalysts show $\mathrm{PdO}$ nanoparticles supported on $\mathrm{y}-\mathrm{Al}_{2} \mathrm{O}_{3}$ (Supplementary Figure 2) and zeolite-Y (Supplementary Figure 3). PdO nanoparticles can be observed as dark spots contrasted against the support, which appear to have smaller average particle size when supported on $\mathrm{\gamma}-\mathrm{Al}_{2} \mathrm{O}_{3}$ compared with zeolite- $\mathrm{Y}$.

After a reduction pre-treatment in $10 \% \mathrm{H}_{2} / \mathrm{He}$, the Pd K-edge XANES of the supported Pd catalysts can be matched to that of Pd foil (Supplementary Figure 4), with small differences attributed to particle size and temperature effects. ${ }^{27}$ By fitting the Fourier transformed Pd K-edge EXAFS spectra of the reduced catalysts (Supplementary Figure 5 and Supplementary Table 1) to a model using a single $\mathrm{Pd}-\mathrm{Pd}$ scattering path, the $\mathrm{Pd}$ coordination number of $\mathrm{Pd} / \mathrm{Y}-\mathrm{Al}_{2} \mathrm{O}_{3}$ and $\mathrm{Pd} /$ zeolite- $\mathrm{Y}$ were found as 9.7 and 11.3, respectively. These values correspond to average particle diameters of $2.1 \mathrm{~nm}$ and $5.2 \mathrm{~nm}$, respectively, calculated using a method reported previously, ${ }^{28}$ and are consistent with the TEM images.

Catalytic Activity. $\mathrm{NH}_{3}$ conversion and product selectivity of the reduced $\mathrm{Pd}$ catalysts during the operando XAFS/DRIFTS/MS experiment were calculated from $\mathrm{m} / z$ signals of $\mathrm{NH}_{3}, \mathrm{~N}_{2}, \mathrm{NO}, \mathrm{N}_{2} \mathrm{O}$ and $\mathrm{NO}_{2}(\mathrm{~m} / z=17,28,30,44$ and 46$)$ relative to the inlet $\mathrm{NH}_{3}$ signal, and are plotted in Figure 1 for $\mathrm{Pd} / \mathrm{Y}-\mathrm{Al}_{2} \mathrm{O}_{3}$ and $\mathrm{Pd} /$ zeolite$\mathrm{Y}$. Both catalysts exhibit similar catalytic activity, achieving $50 \%$ $\mathrm{NH}_{3}$ conversion at $213^{\circ} \mathrm{C}\left(1.5 \mathrm{wt} \% \mathrm{Pd} / \mathrm{Y}-\mathrm{Al}_{2} \mathrm{O}_{3}\right)$ and $190^{\circ} \mathrm{C}(1.5 \mathrm{wt} \%$ $\mathrm{Pd} /$ zeolite-Y), which is close to that reported previously. ${ }^{15}$ The product selectivity to dinitrogen and nitrogen oxides at increasing temperature can be described by three distinct temperature regions; $150^{\circ} \mathrm{C}<T_{1}<240^{\circ} \mathrm{C}, 240^{\circ} \mathrm{C}<T_{2}<300^{\circ} \mathrm{C}$ and $300^{\circ} \mathrm{C}<T_{3}<400^{\circ} \mathrm{C}$. The low temperature regime, $T_{1}$, showed a period of high selectivity to $\mathrm{N}_{2}$.

During the mid-temperature region, $T_{2}, \mathrm{~N}_{2}$ formation reached a plateau and the formation of $\mathrm{N}_{2} \mathrm{O}$ increased steadily. The start of the high temperature region, $T_{3}$, was defined by onset of NO formation and decrease in $\mathrm{N}_{2} \mathrm{O}$ formation. Due to similar properties of both Pd NP catalysts in this study, only results from the $\mathrm{Pd} / \mathrm{\gamma}-\mathrm{Al}_{2} \mathrm{O}_{3}$ catalyst will be discussed hereafter (results from $\mathrm{Pd}$ /zeolite-Y are shown in Supplementary Information).

Pd $\mathrm{L}_{3}$-edge XANES. In situ Pd $\mathrm{L}_{3}$-edge XANES were performed to determine the $\mathrm{Pd}$ electronic structure during $\mathrm{NH}_{3} / \mathrm{O}_{2}$ reaction conditions at low temperature. The $\mathrm{Pd} \mathrm{L}_{3}$-edge XANES of $\mathrm{Pd} / \mathrm{Y}$ $\mathrm{Al}_{2} \mathrm{O}_{3}$ are shown in Figure 2 before and after switching to $\mathrm{NH}_{3} / \mathrm{O}_{2}$ atmosphere, together with a reference spectrum of $\mathrm{Pd}$ hydride collected by cooling the sample to room temperature in $5 \%$ $\mathrm{H}_{2} / \mathrm{He}$. Palladium hydride gives rise to a distinct absorption feature at $3182 \mathrm{eV}$ due to excitation of $2 p$ electrons to a $\mathrm{Pd}-\mathrm{H}$ antibonding state (Figure 2). ${ }^{29-31}$ The XANES spectrum of $\mathrm{Pd} / \mathrm{Y}$ -
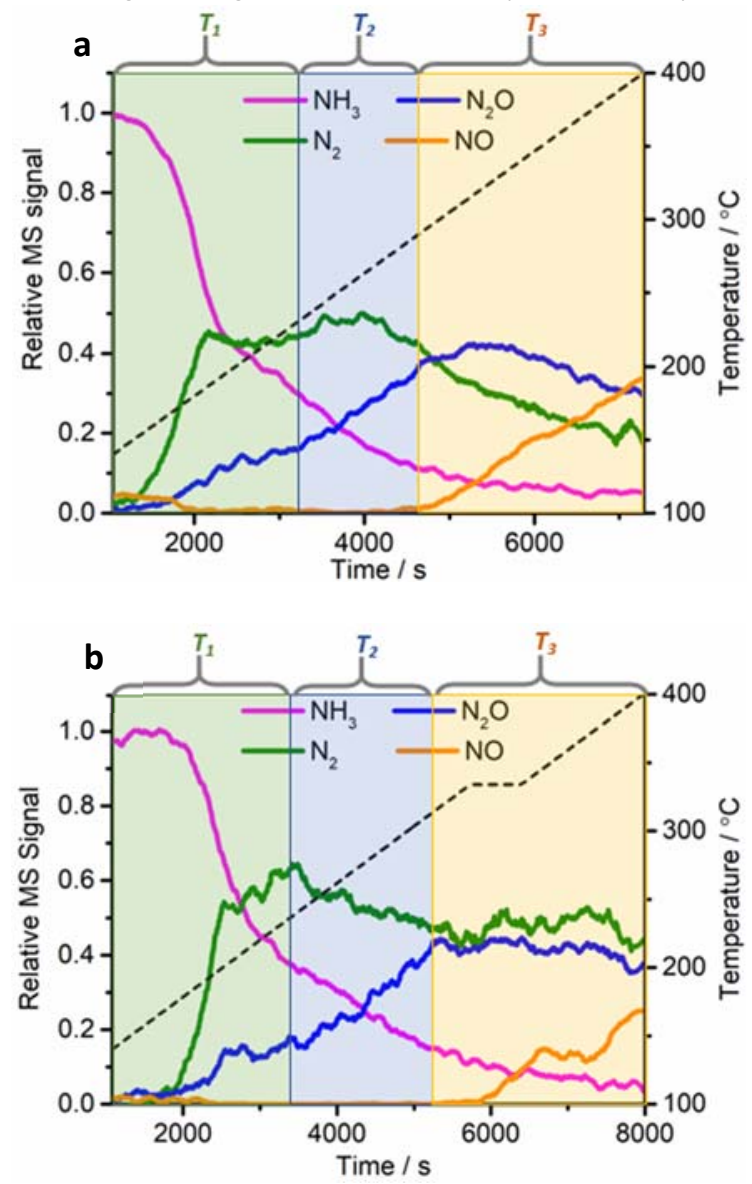

Figure 1. Catalytic activity of supported Pd catalysts for $\mathrm{NH}_{3}$ oxidation at increasing temperatures. a, 1.5wt\% Pd/zeolite-Y. $\boldsymbol{b}$, 1.5wt\% $\mathrm{Pd} / \mathrm{\gamma}-\mathrm{Al}_{2} \mathrm{O}_{3}$. Reactant gas feed: $0.5 \% \mathrm{NH}_{3}, 2.5 \% \mathrm{O}_{2}, 97 \%$ He.

$\mathrm{Al}_{2} \mathrm{O}_{3}$ collected under $\mathrm{He}$ at $100^{\circ} \mathrm{C}$, after a reduction pretreatment (Figure 2), is consistent with that of $\mathrm{Pd}$ foil for metallic $\mathrm{Pd}^{(0)}$ oxidation state. After switching to the reactant $\left(\mathrm{NH}_{3} / \mathrm{O}_{2}\right)$ gas feed at $100^{\circ} \mathrm{C}$, the $\mathrm{Pd} \mathrm{L}_{3}$-edge XANES show increased intensity and broadening of the white line (Figure 2) but without the characteristic absorption feature at $3182 \mathrm{eV}$ for palladium hydride.

The Pd $\mathrm{L}_{3}$-edge XANES spectra confirm there is a change to the $\mathrm{Pd}$ structure upon introducing the reactant $\left(\mathrm{NH}_{3}, \mathrm{O}_{2}\right)$ gas feed that cannot be attributed to formation of palladium hydride. The increase in intensity and broadening of the white line intensity of $\mathrm{Pd} \mathrm{L}_{3}$-edge XANES has previously been reported for the in situ formation of a carbide like phase. ${ }^{22}$ However, the absence of carbon in this system leads us to infer the formation of another type of interstitial structure, palladium nitride. ${ }^{32}$ Upon repeating this procedure with a gas feed of $0.5 \% \mathrm{NH}_{3} / \mathrm{He}$, the same result is obtained (Supplementary Figure 6), showing that the same structural phase is also formed without the presence of $\mathrm{O}_{2}$. Further evidence of the Pd nitride species was inferred from XPS spectra of the sample after treating with $\mathrm{NH}_{3}$ gas. Deconvoluting the peak in the N1s region identifies the presence of two nitrogen species at $402 \mathrm{eV}$ and $398 \mathrm{eV}$ (Supplementary Figure 7). The N1s species located at $400 \mathrm{eV}$ is consistent with $\mathrm{NH}_{3}$ molecular species, whereas the species located at $395 \mathrm{eV}$ is consistent with the formation of a reduced nitrogen as in metal nitrides..$^{32,33}$ 


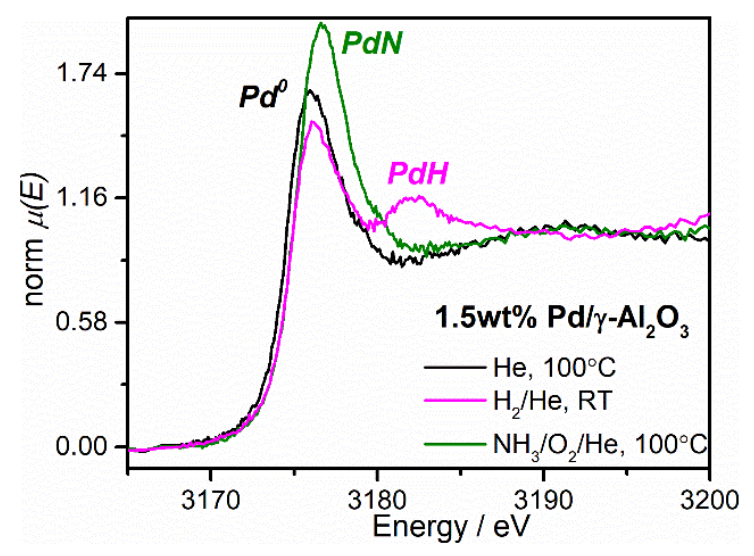

Figure 2. In situ $\mathrm{Pd} \mathrm{L}_{3}$-edge XANES of $\mathrm{Pd} / \mathrm{V}-\mathrm{Al}_{2} \mathrm{O}_{3}$ in different gas environments. XANES collected after in situ reduction in $\mathrm{H}_{2}$ at $200^{\circ} \mathrm{C}$, then exposure to a) inert $\mathrm{He}$ at $100^{\circ} \mathrm{C}$ (black), b) $10 \% \mathrm{H}_{2}$ at room temperature (magenta) and c) $0.5 \% \mathrm{NH}_{3} / 2.5 \% \mathrm{O}_{2} / \mathrm{He}$ at $100^{\circ} \mathrm{C}$ (green).

Operando Pd K-edge XAFS. The change in electronic structure of the $\mathrm{Pd}$ species upon exposure to the reactant $\mathrm{NH}_{3} / \mathrm{O}_{2} / \mathrm{He}$ gas feed is confirmed again by comparison of the Pd K-edge XANES recorded before and after gas switching from inert to $\mathrm{NH}_{3} / \mathrm{O}_{2} / \mathrm{He}$, as seen in Figure 3a. On addition of the reactant $\mathrm{NH}_{3} / \mathrm{O}_{2} / \mathrm{He}$ gas feed, the near edge features at $24393 \mathrm{eV}$ and $24432 \mathrm{eV}$ shifted by $c a .4 \mathrm{eV}$ to lower energies. These observations could be reproduced by exposing the catalyst to a $0.5 \% \mathrm{NH}_{3} / \mathrm{He}$ gas feed (Supplementary Figure 9 ). As oxygen is not required to impart the Pd structural change observed by XANES, we can rule out that these observations are a consequence of oxidation. Moreover, a surface oxidation would result in a different XANES spectrum from that observed, as shown later in Figure 4. The observed change in Pd K-edge XANES features has also been reported for heteroatom insertion inside the metal $\mathrm{Pd}$ fcc framework of supported Pd NPs during in situ formation of a palladium carbide phase, suggesting similar structural and electronic changes to the Pd nanoparticles in this case. ${ }^{24,26}$ These observations again support the proposed formation of an interstitial compound.

The Pd K-edge extended X-ray absorption fine structure (EXAFS) gives information on the average local atomic environment of the absorbing palladium atoms in the sample. Major disruption to the local atomic arrangement of the metallic Pd NPs upon introducing the $\mathrm{NH}_{3} / \mathrm{O}_{2}$ reactant gas mixture (and $\mathrm{NH}_{3} / \mathrm{He}$ only) can be observed by decreased amplitude and phase shift of the $k^{2}$ weighted $\mathrm{Pd}$ K-edge EXAFS oscillations, seen in Figure $3 \mathrm{~b}$, which shows that there must be substantial heteroatom insertion not only to cause expansion of the fcc lattice but also to cause significant disruption of the local atomic ordering. The Fourier transformed EXAFS spectrum (Figure 3c) can be fitted with a model using first shell coordination to nitrogen $\left(R_{P d-N}=\right.$ $2.00 \AA)$ and a second shell coordination to palladium $\left(R_{P d-P d}=2.81\right.$ $\AA ̊$ ), with coordination numbers of 1 and 9.9, respectively (Table 1).
The Pd K-edge XANES spectra collected during the high temperature $\mathrm{NH}_{3}$ oxidation regime are plotted in Figure 4 . The spectrum collected at $240^{\circ} \mathrm{C}$ (plotted in green, Figure 4) shows that the XANES features return to energies that resemble the initial $\mathrm{Pd}^{(0)}$ spectrum collected under inert atmosphere (plotted in black, Figure 4), but with a slight increase in white line intensity and dampening of the metallic feature at $24393 \mathrm{eV}$.

Table 1. Pd K-edge EXAFS fitting parameters of $1.5 w t \% \mathrm{Pd} / \mathrm{Y}$ $\mathrm{Al}_{2} \mathrm{O}_{3}$ at $100^{\circ} \mathrm{C}$ in $0.5 \% \mathrm{NH}_{3} / 2.5 \% \mathrm{O}_{2} / \mathrm{He}$.

\begin{tabular}{|l|l|l|l|l|l|}
\hline $\begin{array}{l}\text { Abs - } \\
\text { Scat }\end{array}$ & $N$ & $R / \AA$ & $\sigma^{2} / \AA^{2}$ & $E_{0} / \mathrm{eV}$ & $\begin{array}{l}R \\
\text { factor }\end{array}$ \\
\hline & & & & & \\
\hline Pd-N & $1.0(2)$ & $2.00(1)$ & $0.003(2)$ & $-5.7(4)$ & 0.02 \\
\hline Pd-Pd & $9.9(1)$ & $2.810(5)$ & $0.0161(8)$ & & \\
\hline
\end{tabular}

Note: Fitting parameters $S_{0}^{2}=0.8$; Fit range $3<k / \AA^{-2}<10.6,1<$ $R / \AA<3$; Number of independent points $=9$.

This flattening of the metallic feature and increase in white line intensity can result from temperature differences, as well as partial oxidation of $\mathrm{Pd}^{(0)}$ to $\mathrm{Pd}^{2+}$ due to $\mathrm{PdO}$ formation. Linear combination fitting (detailed in Supplementary Table 3 and Supplementary Figure 11) describes the Pd K-edge XANES collected at $240^{\circ} \mathrm{C}$ as an approximate summation of $\sim 40 \% \mathrm{Pd}^{(0)}$ and $\sim 60 \% \mathrm{Pd}^{2+}$ species. This fitting used the Pd K-edge XANES spectra collected at $100^{\circ} \mathrm{C}$ in $\mathrm{He}$ and at $300^{\circ} \mathrm{C}$ in $\mathrm{NH}_{3} / \mathrm{O}_{2}$ to represent $\mathrm{Pd}^{(0)}$ and $\mathrm{Pd}^{2+}$ species of this particle size, respectively. The ratio of $40 \% \mathrm{Pd}^{(0)}$ and $60 \% \mathrm{Pd}^{2+}$ is expected for a thin oxidic surface layer of supported Pd NPs of approximately $2 \mathrm{~nm}$ diameter, as reported previously. ${ }^{34}$ The greater ratio of $\mathrm{Pd}$ located at the surface of small NPs has significant contribution to the averaged Pd signal of the measured XANES spectrum.

The Fourier transformed EXAFS of the sample at $240^{\circ} \mathrm{C}$, shown in Supplementary Figure 12, shows scattering features at 1.8 and $2.6 \AA ̊$ for first shell Pd-O and Pd-Pd neighbours, respectively, but absence of a second shell $\mathrm{Pd}-\mathrm{Pd}_{(2)}$ scattering feature related to a bulk Pd oxide, expected at $3.01 \AA$. These observations confirm that any $\mathrm{Pd}-\mathrm{O}$ formation at $240^{\circ} \mathrm{C}$ is short range and limited only to the Pd NP surface.

At temperatures beyond $240^{\circ} \mathrm{C}$, the white line intensity of $\mathrm{Pd} \mathrm{K}$ edge XANES spectra increase further and metallic features diminish such that the XANES spectrum collected at $300^{\circ} \mathrm{C}$ (plotted in orange, Figure 4) resembles that of a bulk PdO phase. The Fourier transformed Pd K-edge EXAFS spectra (Supplementary Figure 12) show major transition from metallic NP structure at $240^{\circ} \mathrm{C}$ to oxide NP structure at $300^{\circ} \mathrm{C}$, and growth in amplitude of the oxide scattering features from $300^{\circ} \mathrm{C}$ to $340^{\circ} \mathrm{C}$. The Fourier transformed EXAFS of the sample at $340^{\circ} \mathrm{C}$ can be fitted to a model using scattering paths of $\mathrm{Pd}-\mathrm{O}\left(R_{\mathrm{Pd}-\mathrm{O}}=\right.$ $2.01 \AA$ ) , $\mathrm{Pd}-\mathrm{Pd}_{(1)}\left(R_{\mathrm{Pd}-\mathrm{Pd} 1}=3.01 \AA\right)$ and $\mathrm{Pd}-\mathrm{Pd}_{(2)}\left(R_{\mathrm{Pd}-\mathrm{Pd} 2}=3.455 \AA\right)$, with coordination numbers $3.7(3), 1.0(9)$ and $2(2)$, respectively (Supplementary Figure 13 and Supplementary Table 4). 

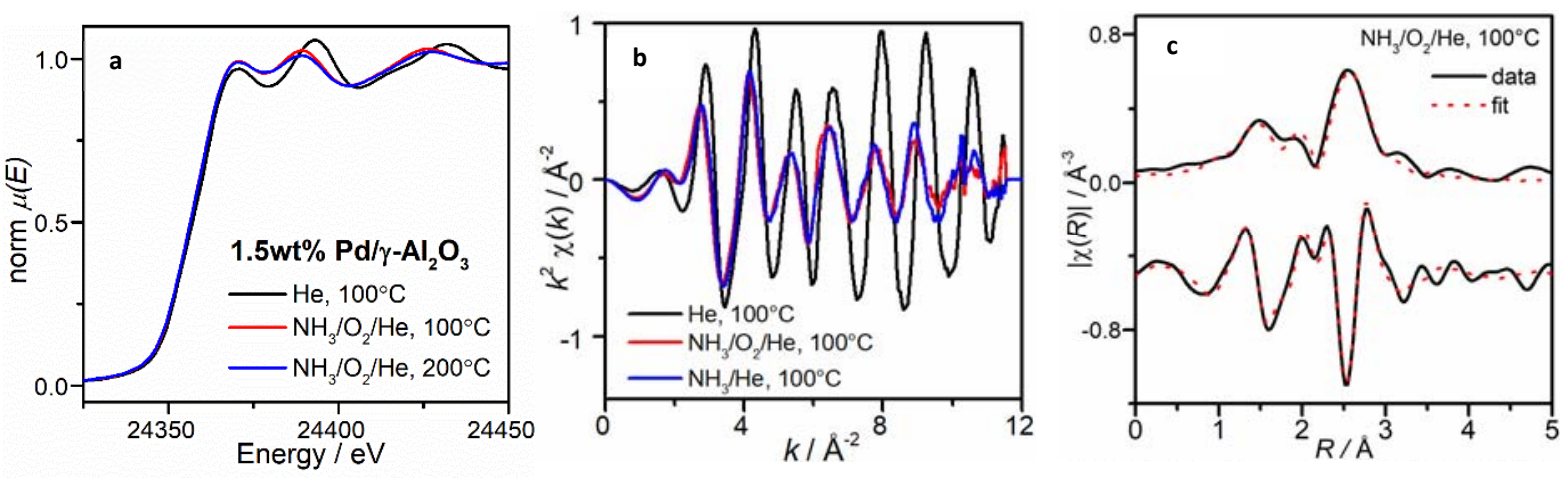

Figure 3. Operando Pd K-edge XANES and EXAFS of $\mathrm{Pd} / \mathrm{v}-\mathrm{Al}_{2} \mathrm{O}_{3}$ in different reaction conditions. a, $\mathrm{Pd} \mathrm{K}$-edge $\mathrm{XANES}$ of $1.5 \mathrm{Wt} \% \mathrm{Pd} / \mathrm{\gamma}-\mathrm{Al} \mathrm{I}_{2} \mathrm{O}_{3}$ after reduction pre-treatment in $\mathrm{H}_{2}$, then exposure to a) $\mathrm{He}$ at $100^{\circ} \mathrm{C}$ (black), b) $0.5 \% \mathrm{NH}_{3} / 2.5 \% \mathrm{O}_{2} / \mathrm{He}$ at $100^{\circ} \mathrm{C}(\mathrm{red})$ and c) $0.5 \% \mathrm{NH} / 2.5 \%$ $\mathrm{O}_{2} / \mathrm{He}$ at $200^{\circ} \mathrm{C}$ (blue). b, $\mathrm{Pd} \mathrm{K}$-edge $\mathrm{k}^{2}$ weighted EXAFS of $1.5 \mathrm{wt} \% \mathrm{Pd} / \mathrm{V}-\mathrm{Al} \mathrm{I}_{2} \mathrm{O}_{3}$ after reduction pre-treatment, then exposure to a) He (black) and b) $0.5 \% \mathrm{NH}_{3} / 2.5 \% \mathrm{O}_{2} / \mathrm{He}$ (red) and c) $0.5 \% \mathrm{NH}_{3} / \mathrm{He}$ (blue) at $100^{\circ} \mathrm{C}$. c, Stacked plot of magnitude (top) and imaginary (bottoms) nonphase corrected Fourier transformed Pd K-edge EXAFS of $1.5 \mathrm{wt} \% \mathrm{Pd} / \mathrm{\gamma}-\mathrm{Al}_{2} \mathrm{O}_{3}$ at $100^{\circ} \mathrm{C}$ in $0.5 \% \mathrm{NH}_{3} / 2.5 \%$ O $\mathrm{O}_{2} / \mathrm{He}$ atmosphere, plotted with fit constructed from $P d-N$ and $P d-P d$ scattering paths.

Operando Pd K-edge XAFS have therefore identified three structural phases of Pd NPs during $\mathrm{NH}_{3}$ oxidation. The first is a $\mathrm{PdN}_{x}$ species that forms during the low temperature regime $\left(100^{\circ} \mathrm{C} \leq T_{1} \leq 200^{\circ} \mathrm{C}\right)$, where the main product of $\mathrm{NH}_{3}$ oxidation is $\mathrm{N}_{2}$. The second is a Pd NP with bulk metallic structure and a surface oxide that forms in the mid-temperature regime $\left(240^{\circ} \mathrm{C}\right.$ $<T_{2}<300^{\circ} \mathrm{C}$ ), where an increasing amount of $\mathrm{NH}_{3}$ is oxidised to $\mathrm{N}_{2} \mathrm{O}$. The third structural phase is a bulk PdO NP formed at high temperature $\left(T_{3}>300^{\circ} \mathrm{C}\right)$, which is linked to the production of NO.

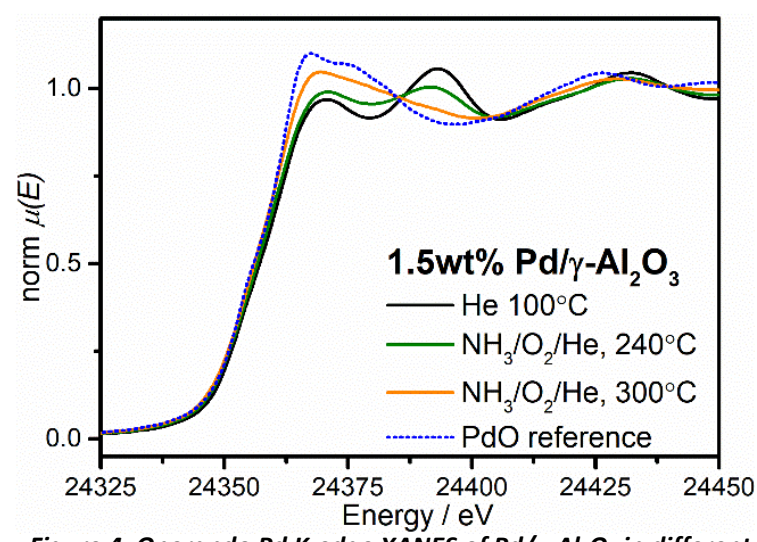

Figure 4. Operando $\mathrm{Pd} \mathrm{K}$-edge XANES of $\mathrm{Pd} / \mathrm{V}-\mathrm{Al}_{2} \mathrm{O}_{3}$ in different reaction conditions. Pre-treatment in $\mathrm{H}_{2}$, then exposure to $\mathrm{He}$ at $100^{\circ} \mathrm{C}$ (black), $0.5 \% \mathrm{NH}_{3} / 2.5 \% \mathrm{O}_{2} / \mathrm{He}$ at $240^{\circ} \mathrm{C}$ (green) and $300^{\circ} \mathrm{C}$ (orange). Pd K-edge XANES of bulk PdO at ambient conditions shown as reference (blue, dashed).

Operando DRIFTS. Figure 5 shows the difference DRIFTS spectrum of catalyst $\mathrm{Pd} / \mathrm{V}-\mathrm{Al}_{2} \mathrm{O}_{3}$, collected simultaneously with the XAFS, after switching from inert He to the reactant $\mathrm{NH}_{3} / \mathrm{O}_{2}$ gas feed at $100^{\circ} \mathrm{C}$. The sharp bands between 1250 and $1600 \mathrm{~cm}^{-}$ ${ }^{1}$ are typical of $\mathrm{NH}_{3}$ adsorbed to surface acid sites. The bands at $1596 \mathrm{~cm}^{-1}$ and $1256 \mathrm{~cm}^{-1}$ are assigned to asymmetric and symmetric deformation of coordinated ammonia, respectively. ${ }^{14-17}$ The band at $1450 \mathrm{~cm}^{-1}$ can be assigned to asymmetric deformation of ammonium ions adsorbed on Brønsted sites of the support, ${ }^{14,18-20}$ and the shoulder at $1490 \mathrm{~cm}^{-}$ ${ }^{1}$ to $\mathrm{NH}_{3}$ coordinated to Pd. ${ }^{11}$ Low intensity combination bands of ammonia and ammonia dimers may give rise to the broad band around $2470 \mathrm{~cm}^{-1} \cdot{ }^{35}$ Absorption bands between 3080 and 3480 $\mathrm{cm}^{-1}$ are typical of symmetric and asymmetric N-H stretching of coordinated ammonia. ${ }^{36,37}$ Negative bands above $3500 \mathrm{~cm}^{-1}$ show the absence of $\mathrm{O}-\mathrm{H}$ stretches due to $\mathrm{NH}_{4}{ }^{+}$occupying surface hydroxyl Brønsted acid sites. The dissociative adsorption of ammonia on the $\mathrm{Pd}$ nanoparticle surface is shown by a weak band at $1377 \mathrm{~cm}^{-1}$ which is attributed to the $-\mathrm{NH}_{2}$ wagging frequency ${ }^{12,38}$, usually coupled with the band at $1596 \mathrm{~cm}^{-1}$. The broad, low intensity band at $1850 \mathrm{~cm}^{-1}$ is attributed to small amounts of neutral and positively charged nitrosyl $\left(\mathrm{NO}^{+}\right)$species adsorbed on $\mathrm{Pd}^{(0)}{ }^{39}$ The broad band of small intensity at 2170 $\mathrm{cm}^{-1}$ is present in the DRIFTS spectrum of both catalysts after switching to the $\mathrm{NH}_{3} / \mathrm{O}_{2}$ reactant gas feed at $100^{\circ} \mathrm{C}$, and when switching to an $\mathrm{NH}_{3} / \mathrm{He}$ atmosphere (Supplementary Figure 14). Absorption bands at this wavenumber have previously been associated with the vibrational frequency of an asymmetric N-N bond of bridging $\mathrm{N}_{2}$ in multinuclear metal-dinitrogen complexes. ${ }^{22}$ The observation of vibrational bands near $2200 \mathrm{~cm}^{-}$ ${ }^{1}$ during $\mathrm{NH}_{3}$ oxidation conditions are sometimes attributed to the $\mathrm{N}-\mathrm{N}$ stretch of adsorbed $\mathrm{N}_{2} \mathrm{O}$ species. ${ }^{40,41}$ However, the absence of a corresponding $\mathrm{N}-\mathrm{O}$ stretch for $\mathrm{N}_{2} \mathrm{O}$ (expected at $1262-1220 \mathrm{~cm}^{-1}$ ) and absence of $\mathrm{N}_{2} \mathrm{O}$ detected in mass spectrometry signals at $100^{\circ} \mathrm{C}$ means that the band at $2170 \mathrm{~cm}^{-1}$ cannot be assigned to $\mathrm{N}_{2} \mathrm{O}$ species at this temperature. Similar vibrational bands at $2170 \mathrm{~cm}^{-1}$ are observed in the DRIFTS spectrum of $1.5 \mathrm{wt} \% \mathrm{Pd} /$ Zeolite under analogous conditions (Supplementary Figure 19 and Supplementary Figure 20) and are reported for $\mathrm{NH}_{3}$ adsorption over an $\mathrm{Ag} / \mathrm{Al}_{2} \mathrm{O}_{3}$ catalyst between $160-220^{\circ} \mathrm{C}$, which also cannot be attributed to N-N stretching of $\mathrm{N}_{2} \mathrm{O}^{37}$ We propose that this low intensity absorption band results from an asymmetric stretch of dinitrogen species at the catalyst surface, following the dissociated adsorption of ammonia molecules. An absorption band at $1455 \mathrm{~cm}^{-1}$ due to $\mathrm{NH}$ wagging at the sample surface decreases in intensity from $200^{\circ} \mathrm{C}$ to $220^{\circ} \mathrm{C}$ followed by formation of small intensity bands at 1418,1302 and $1548 \mathrm{~cm}^{-1}$ (Supplementary Figure 15) due to the formation of adsorbed nitrate species. ${ }^{37,42-44}$ The intensity of these nitrate bands increase sharply at $280^{\circ} \mathrm{C}$, suggesting the onset of NO formation at the catalyst surface which are then desorbed and detected in the mass spectrometer from $300^{\circ} \mathrm{C}$. 


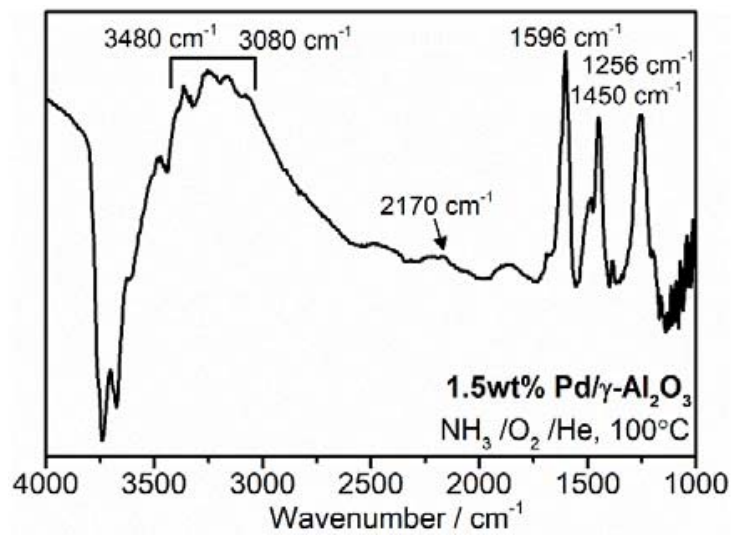

Figure 5. Operando DRIFTS spectrum of $\mathrm{Pd} / \mathrm{v}-\mathrm{Al}_{2} \mathrm{O}_{3}$ during $\mathrm{NH}_{3}$ oxidation. Difference DRIFTS spectrum between spectrum collected after reduction pre-treatment in He and in 0.5\% $\mathrm{NH}_{3} / 2.5 \% \mathrm{O}_{2} /$ He reactant gas at $100^{\circ} \mathrm{C}$.

DFT + D3 Calculations. To clarify how the presence of interstitial $\mathrm{N}$-atoms influence the Pd-Pd bond distances, DFT+D3 calculations were performed. These calculations were done in the $\operatorname{Pd}(111)$ system with $0.12 \mathrm{wt} \%, 0.23 \mathrm{wt} \%, 0.47 \mathrm{wt} \%, 0.70$ $\mathrm{wt} \%$, and $1.39 \mathrm{wt} \%$ of interstitial $\mathrm{N}$-atoms (optimised structures shown in Supplementary Figure 21), which showed that the average $\mathrm{Pd}$-Pd distances in the vicinity of interstitial $\mathrm{N}$-atoms are $\sim 2.83 \AA$ A. This is consistent with the lattice expansion observed by $\mathrm{Pd}$ K-edge EXAFS during $\mathrm{N}$-atom insertion under $\mathrm{NH}_{3} / \mathrm{O}_{2}$ reaction conditions. The lateral and vertical Pd-Pd distances were found to be in the range of $2.83-2.85 \AA$ and $2.80-2.83 \AA$, respectively, irrespective of the concentration of $\mathrm{N}$-atom insertion. The Pd-N distances were in the range $1.91-1.99 \AA$, which is in agreement with the distances found from the Pd K-edge EXAFS data. Before relaxation, distances between the interstitial $\mathrm{N}$-atoms in all the above models were in the range of $2.39-2.47 \AA$ and after relaxation these moved by a distance approximately in the range of 3.03-3.34 $\AA$, with some of the $\mathrm{N}$-atoms moving closer to the surface. The diffusion barrier for an interstitial $\mathrm{N}$-atom to move from an octahedral interstitial site to a surface 3 -fold hollow was low $(0.25 \mathrm{eV})$, suggesting that interstitial $\mathrm{N}$-atoms are able to diffuse to the surface to participate in the catalytic mechanism.

The adsorption properties of $\mathrm{NH}_{3}$ on $\mathrm{Pd}(111)$ surface were considered with and without the presence of interstitial $\mathrm{N}$ atoms. The adsorption energies of $\mathrm{NH}_{3}$ molecule close to the interstitial $\mathrm{N}$-atom is more favourable as compared to away from it in the same system, and also in comparison to the pristine $\mathrm{Pd}(111)$ surface by $\sim 0.156 \mathrm{eV}$ (all calculated adsorption energies of $\mathrm{NH}_{3}$ on $\mathrm{Pd}(111)$ surface with and without interstitial $\mathrm{N}$-atoms are given in Supplementary Tables 6, 7 and 8). This is due to the interaction of $\mathrm{N} p$ and $\mathrm{Pd} d$ molecular orbitals in the bonding region. For pristine $\mathrm{Pd}(111)$ surface the $\mathrm{Pd} d_{z^{2}}$ orbital interacts with the $\mathrm{N} p$ orbitals whereas in the case of a $\mathrm{Pd}(111)$ surface with an interstitial $\mathrm{N}$-atom the $\mathrm{Pd} d_{z^{2}}$ and $\mathrm{d}_{\mathrm{yz}}$ interact with the $\mathrm{N}$ $p$ orbital leading to a stronger bonding interaction between $\mathrm{Pd}$ atoms with $\mathrm{NH}_{3}$ molecules. In the latter case there is also trace contribution from other $d$ orbitals. From this analysis we can conclude that the $\mathrm{Pd}(111)$ surface with interstitial $\mathrm{N}$-atoms would have greater coverage of adsorbed $\mathrm{NH}_{3}$ as compared to the pristine $\mathrm{Pd}(111)$ surface.

\section{Discussion}

Three distinct regions of catalytic activity are identified for $\mathrm{NH}_{3}$ oxidation over supported Pd NP catalysts. During the low temperature region $\left(100^{\circ} \mathrm{C} \leq T_{1} \leq 200^{\circ} \mathrm{C}\right)$, the $\mathrm{Pd} \mathrm{K}$-edge and $\mathrm{Pd}$
L3-edge XANES show that the palladium structure experiences lattice expansion with insertion of nitrogen into the metallic $\mathrm{Pd}$ NP structure, which is confirmed by our DFT+D3 calculations. The dissociation of $\mathrm{NH}_{3}$ during this temperature region is shown by $-\mathrm{NH}_{2}$ scissoring (at $1377 \mathrm{~cm}^{-1}$ ), $-\mathrm{NH}$ wagging $\left(1455 \mathrm{~cm}^{-1}\right.$ ) and a low intensity vibrational band at $2170 \mathrm{~cm}^{-1}$ for $\mathrm{N}-\mathrm{N}$ stretching at the catalyst surface. The greater stability of $\mathrm{NH}_{3}$ adsorption on the Pd nitride NP surface is calculated from molecular models and infers a high $\mathrm{NH}_{3}$ surface coverage. Additionally, the low energy barrier for diffusion of interstitial $N$ to the surface indicates the ability for interstitial $\mathrm{N}$ to participate in the reaction mechanism by coupling with adsorbed $\mathrm{NH}_{3}$ at the NP surface in a Mars Van Krevelen type mechanism. Indeed, a small contribution of $m / z 28$ for $N_{2}$ gas is detected by on-line MS at $100^{\circ} \mathrm{C}$, which increases sharply at $150^{\circ} \mathrm{C}$ in line with $\mathrm{NH}_{3}$ conversion. By correlating the N-N surface species, Pd NP structure and $\mathrm{N}_{2}$ formation (Supplementary Figure 22) the N-N surface species are only observed when the Pd nanoparticles exist as $\mathrm{PdN}_{x}$, and the desorption of such species coincides with the onset of $\mathrm{N}_{2}$ formation. Following this, the contraction of the $\mathrm{Pd}$ distance - indicating the removal of interstitial $\mathrm{N}$ from the $\mathrm{Pd}$ lattice - is found to occur when $\mathrm{N}_{2}$ formation exceeds $50 \%$, relative to the inlet $\mathrm{NH}_{3}$. This suggests the involvement of interstitial $\mathrm{N}$ in the reaction mechanism for the selective oxidation of $\mathrm{NH}_{3}$ to $\mathrm{N}_{2}$ (Equation 1), which are depleted when the rate of consumption is greater than the rate of replacement.

$4 \mathrm{NH}_{3}+3 \mathrm{O}_{2} \rightarrow 2 \mathrm{~N}_{2}+6 \mathrm{H}_{2} \mathrm{O}$

The active $\mathrm{PdN}_{x}$ NP structure is observed by operando Pd K-edge and $\mathrm{Pd} \mathrm{L}_{3}$-edge XANES up to $200^{\circ} \mathrm{C}$. At temperatures beyond $200^{\circ} \mathrm{C}$, the interstitial $\mathrm{N}$ is removed from the Pd lattice and the Pd K-edge XANES show that the structure of the Pd NPs return to predominantly a metallic oxidation state, with a small oxidic surface layer. During this period DRIFTS spectra show the presence of 2240 and $2210 \mathrm{~cm}^{-1}$ absorption bands for $\mathrm{N}_{2} \mathrm{O}$ molecular vibrations beyond $180^{\circ} \mathrm{C}$ and there is an increase in $\mathrm{N}_{2} \mathrm{O}$ gas reaching the mass spectrometer. Therefore an increasing number of $\mathrm{NH}_{3}$ molecules are oxidised to $\mathrm{N}_{2} \mathrm{O}$ at the Pd surface, as per Equation 2. The formation of $\mathrm{N}_{2}$, as detected by MS can result from the $\mathrm{NH}_{3}-\mathrm{SCR}$ reaction of adsorbed $\mathrm{N}_{2} \mathrm{O}$ with incoming gaseous $\mathrm{NH}_{3}$, as in Equation $3 .{ }^{45}$

$$
\begin{aligned}
& 2 \mathrm{NH}_{3}+2 \mathrm{O}_{2} \rightarrow \mathrm{N}_{2} \mathrm{O}+3 \mathrm{H}_{2} \mathrm{O} \\
& 2 \mathrm{NH}_{3}+3 \mathrm{~N}_{2} \mathrm{O} \rightarrow 4 \mathrm{~N}_{2}+3 \mathrm{H}_{2} \mathrm{O}
\end{aligned}
$$

The presence of surface nitrate absorption bands are first observed in the DRIFTS spectra (as absorption bands at 1418, 1302 and $1548 \mathrm{~cm}^{-1}$ ) at $280^{\circ} \mathrm{C}$ and increase significantly in intensity at higher temperatures. Nitrate formation at the catalyst surface correlates with the temperature for bulk oxidation of the Pd NPs, observed by change in Pd K-edge XANES, and is followed by onset of NO gas, observed by MS, at temperatures $\geq 300^{\circ} \mathrm{C}$. The complete oxidation of the Pd NPs is confirmed by fitting the Pd K-edge EXAFS data collected at $340^{\circ} \mathrm{C}$ to $\mathrm{Pd}-\mathrm{O}$ and $\mathrm{Pd}-\mathrm{Pd}$ paths of $\mathrm{PdO}$. The over oxidation of $\mathrm{NH}_{3}$ to NO, by Equation 4, has previously been attributed to high oxygen coverage at the precious metal surface which prevents $\mathrm{N}$ coupling, ${ }^{23}$ but this study indicates that bulk oxide precious metal NPs are the active catalytic species for $\mathrm{NH}_{3}$ oxidation to NO above $280^{\circ} \mathrm{C}$.

$4 \mathrm{NH}_{3}+5 \mathrm{O}_{2} \rightarrow 4 \mathrm{NO}+6 \mathrm{H}_{2} \mathrm{O}$

The powerful combination of XAFS and DRIFTS spectroscopy, together with online mass spectrometry and DFT calculations 
have allowed thorough characterisation of the structure and surface reactivity of supported $\mathrm{Pd} N \mathrm{NPs}$ during reaction for $\mathrm{NH}_{3}-$ $\mathrm{SCO}$. The use of in situ Pd $\mathrm{L}_{3}$-edge and operando Pd K-edge XAFS have identified a $\mathrm{PdN} \mathrm{N}_{\mathrm{x}}$ species in the presence of $\mathrm{NH}_{3} / \mathrm{O}_{2}$ reactant gas feed which exists between $100-200^{\circ} \mathrm{C}$ and is responsible for nitrogen coupling and dinitrogen formation in the direct oxidation pathway. During the mid-temperature range $240^{\circ} \mathrm{C}<$ $T_{2}<300^{\circ} \mathrm{C}$, the catalyst comprises metallic Pd NPs with a surface oxidic layer which permits the formation of $\mathrm{N}_{2}$ and $\mathrm{N}_{2} \mathrm{O}$. The formation of bulk PdO NPs is achieved at higher temperatures, $T_{3}>300^{\circ} \mathrm{C}$, and coincides with the formation of nitrates at the catalyst surface and onset of $\mathrm{NO}$ gas as a reaction product. Therefore the selectivity of the catalytic $\mathrm{NH}_{3}$ oxidation can be attributed to the Pd NP structure, with preferred selectivity to $\mathrm{N}_{2}$ achieved from a previously unidentified $\mathrm{PdN}_{\mathrm{x}}$ species. Whereas the unfavourable over-oxidation to NO occurred at the surface of bulk PdO NPs.

\section{Methods}

Sample Preparation. Supported $1.5 w t \%$ Pd catalysts were prepared by incipient wetness impregnation of an acidified aqueous solution of palladium nitrate $(15.11 \mathrm{wt} \% \mathrm{Pd}$, Johnson

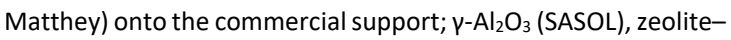
$Y$ (Zeolyst, CBV600, $\mathrm{H}$-form, $\mathrm{SiO}_{2} / \mathrm{Al}_{2} \mathrm{O}_{3}$ molar ratio of 5.2 ). Incipient wetness impregnation was carried out at room temperature. The impregnated supports were subsequently dried at $100^{\circ} \mathrm{C}$, then calcined in air at $500^{\circ} \mathrm{C}$ for 2 hours.

Ex situ Characterisation. TEM images of the samples were obtained using a JEOL JEM 2100 transmission electron microscope. Samples were prepared for TEM analysis by dispersing in high-purity ethanol using ultrasonication. $10 \mu \mathrm{L}$ of the sonicated suspension were pipetted onto a holey carbon supporting Cu grid, and the solvent evaporated. XPS analysis was performed with a Kratos AXIS UItra DLD apparatus, equipped with monochromated $\mathrm{Al} \mathrm{K} \alpha$ radiation X-ray source, a charge neutralizer and a hemispherical electron energy analyser. During data acquisition, the chamber pressure was kept below 10-9 mbar. The spectra were analysed using the CasaXPS software pack and corrected for charging using $C$ 1s binding energy (BE) as the reference at $284.8 \mathrm{eV}$.

Operando Pd L3-edge XANES. Operando Pd L3-edge XANES ( 3175 $\mathrm{eV}$ ) were collected in fluorescence mode at the XMaS beamline of the ESRF. The catalyst sample (125-250 $\mu \mathrm{m}$ pellet fraction) was contained between two Kapton windows as a packed bed within a $100 \mu \mathrm{m}$ trench of a flow reactor, reported elsewhere. ${ }^{46}$ The reactor was mounted within a He chamber and connected to gas lines for flow of reactant gases to the sample. The effluent flow from the reactor was sent to a Hiden QGA mass spectrometer. The temperature was controlled by a thermocouple inserted close to the catalyst bed. The energy range $(3150-3220 \mathrm{eV})$ was selected using a double crystal Si (III) monochromator and spectra were collected using a fluorescence detector at $90^{\circ} \mathrm{C}$ to the $\mathrm{X}$-ray beam and with the sample orientated $45^{\circ}$ to the incoming beam. Each scan measured 265 points with a counting time of 5 seconds per point, taking a total time of 22 minutes per spectrum. The experimental procedure consisted of online pre-treatment at $200^{\circ} \mathrm{C}$ in a reducing $(5 \%$ $\mathrm{H}_{2} / \mathrm{He}$ ) atmosphere. The reactant gas mixture was introduced $\left(0.5 \% \mathrm{NH}_{3}, 2.5 \% \mathrm{O}_{2}, 97 \% \mathrm{He}\right)$ at $100^{\circ} \mathrm{C}$ with a total flow of $40 \mathrm{ml}$ $\mathrm{min}^{-1}$, before ramping $2.5^{\circ} \mathrm{C} \mathrm{min}-1$ to $200^{\circ} \mathrm{C}$. The Pd hydride was formed in situ by cooling the sample to room temperature in $10 \% \mathrm{H}_{2} / \mathrm{He}$. The Pd nitride was formed by introducing $0.5 \%$ $\mathrm{NH}_{3} / \mathrm{He}$ to the reduced catalyst at $100^{\circ} \mathrm{C}$.
Operando Pd K-edge XAFS/DRIFTS/MS. Operando XAFS and DRIFTS measurements were conducted at SuperXAS X10DA, Swiss Light Source, Paul Scherrer Institute, using a previously reported Harrick DRIFTS cell| ${ }^{47-49}$ integrated with an Agilent Carey 680 FTIR spectrometer. A DaVinci arm accessory fitted with praying mantis optics was used to refocus the IR beam outside the FTIR spectrometer for positioning of the Harrick DRIFTS cell in the X-ray path. The Harrick DRIFTS cell has an X-ray path length of $3.17 \mathrm{~mm}$ through the sample positioned $1.04 \mathrm{~mm}$ below the surface of the catalyst bed. The experiment used a controlled flow of mixed gases into the reaction chamber under atmospheric pressure using Brooks mass flow controllers, and the temperature of the catalyst controlled and monitored by a thermocouple positioned inside the catalyst bed. Each run used $\sim 10 \mathrm{mg}$ of pelletized $(125-250 \mu \mathrm{m})$ catalyst. XAFS measurements were performed at the $\mathrm{Pd} \mathrm{K}$-edge $(24358 \mathrm{eV})$ in transmission mode using QEXAFS setup with an oscillating $\mathrm{Si}(311)$ double crystal monochromator operating at $1 \mathrm{~Hz}$. All XAFS spectra were acquired with a Pd foil placed between $I_{t}$ and $I_{r}$, and the time resolution was 0.5 seconds per spectrum $\left(k_{\max }=16.2\right)$. DRIFTS spectra were collected taking 64 scans with a resolution of $4 \mathrm{~cm}^{-}$ ${ }^{1}$ using the liquid nitrogen cooled MCT detector. The time resolution of DRIFTS were 30 seconds per spectrum $(400-4000$ $\left.\mathrm{cm}^{-1}\right)$. At the same time, the composition of effluent gas was measured using a mass spectrometer (Hiden QGA) for $\mathrm{H}_{2}(\mathrm{~m} / \mathrm{z}=$ $2)$, $\mathrm{He}(m / z=4), \mathrm{NH}_{3}(m / z=17), \mathrm{H}_{2} \mathrm{O}(m / z=18), \mathrm{N}_{2}(m / z=28)$, $\mathrm{NO}(m / z=30), \mathrm{O}_{2}(m / z=32), \mathrm{N}_{2} \mathrm{O}(m / z=44)$ and $\mathrm{NO}_{2}(m / z=46)$. The experimental procedure consisted of online pre-treatment at $400^{\circ} \mathrm{C}$ in a reducing $\left(5 \% \mathrm{H}_{2} / \mathrm{He}\right)$ atmosphere, then cooling to $100^{\circ} \mathrm{C}$ in $\mathrm{He}$. The reactant gas mixture was introduced $\left(0.5 \% \mathrm{NH}_{3}\right.$, $2.5 \% \mathrm{O}_{2}, 97 \% \mathrm{He}$ ) at $100^{\circ} \mathrm{C}$ with a total flow of $40 \mathrm{ml} \mathrm{min}^{-1}$, before

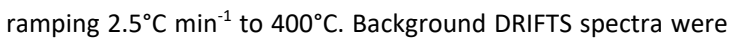
recorded in flowing $\mathrm{He}$ at $100^{\circ} \mathrm{C}$ and subtracted from the sample spectrum for each measurement.

DFT + D3 Calculations. All the spin polarized periodic density functional theory based calculations were performed using Vienna Ab Initio Simulation Package (VASP). ${ }^{50-52}$ The projector augmented wave (PAW) method was used and the cut-off energy for the expansion of the plane-wave basis sets was set to $550 \mathrm{eV}$, which gave bulk energies converged to within $10-5 \mathrm{eV}^{53}$ A convergence criterion of $0.01 \mathrm{eV} \AA^{-1}$ was chosen for structural optimizations and a k-point grid of $3 \times 3 \times 1$ was employed for all slab calculations. Benchmark calculations were used to check the results obtained with Monkhorst-Pack k-point grids of different grid densities, detailed in Supplementary Note 1, which gave negligible differences in calculated adsorption energies (Supplementary Table 9). A smearing value of 1 was used, which is recommended in the VASP manual to be appropriate for metals, ${ }^{54}$ and a partial occupancy value of $0.2 \mathrm{eV}$. Benchmark calculations were used (detailed in Supplementary Note 2) to check the influence of the partial occupancy value on the calculated adsorption energies (Supplementary Table 10). The Perdew-Burke-Ernzerhof (PBE) version of generalized gradient approximation (GGA) was used to carry out geometry optimizations and the total energy calculations. ${ }^{55}$ The ideal $\mathrm{Pd}(111)$ surfaces were modelled by a $2 \times 2$ cell with seven atomic layers. For calculations involving the adsorption of $\mathrm{NH}_{3}$, of the seven atomic layers the bottom four layers were fixed to mimic the bulk of the material. The slabs were cut from bulk Pd with a calculated energy minimized lattice constant of $3.904 \AA$ (which compares well with the experimental value of $3.891 \AA$ ) while in the direction perpendicular to the surface, a vacuum gap of $\sim 15$ $\AA$ A was used. To check the increase in the Pd-Pd distances due to the presence of interstitial $\mathrm{N}$-atoms series of calculations were performed by systematically increasing the number of $\mathrm{N}$-atoms 
at the interstitial positions. For all these calculations, we placed the interstitial $\mathrm{N}$-atoms at the centre of the octahedral sites that are close to both the exposed surfaces and relaxed the atomic coordinates within a fixed cell. This study was extended to clarify the influence of the interstitial $\mathrm{N}$-atoms on the adsorption properties of $\mathrm{NH}_{3}$ molecule on the $\mathrm{Pd}(111)$ surface. The adsorption of the $\mathrm{NH}_{3}$ molecule was allowed on only one of the two exposed surfaces. The dipole moment, due to the adsorbed species, was taken into account by using the methods implemented in VASP according to the procedures of Markov et al. and Neugebauer et al. ${ }^{56,57}$ In this study we have also employed Grimme's dispersion correction (DFT+D3) as dispersive effects might be significant for such systems. ${ }^{58}$ The climbing-image nudged elastic band (Cl-NEB) method was employed to determine the minimum energy path for evaluating the activation energy barrier for the diffusion of interstitial $\mathrm{N}$ atom. ${ }^{59,60}$

Data Availability. The data that support the findings of this study are available from the University of Southampton repository with the identifier 10.5258/SOTON/D0709

Competing Interests. The authors declare no competing interests.

\section{References}

1. Sobczyk, D. P., Hensen, E. J. M., de Jong, A. M. \& van Santen, R. A. Low-Temperature Ammonia Oxidation Over Pt/ $\mathrm{Y}^{-}$ Alumina: The Influence of the Alumina Support. Top. Catal. 23, 109-117 (2003).

2. Weststrate, C. J., Bakker, J. W., Gluhoi, A. C., Ludwig, W. \& Nieuwenhuys, B. E. Ammonia oxidation on $\operatorname{Ir}\left(\begin{array}{lll}1 & 1 & 1\end{array}\right)$ : Why Ir is more selective to N2 than Pt. Catal. Today 154, 46-52 (2010).

3. Hung, C.-M. Characterization and performance of Pt-Pd-Rh cordierite monolith catalyst for selectivity catalytic oxidation of ammonia. J. Hazard. Mat. 180, 561-565 (2010).

4. Gang, L., Anderson, B. G., van Grondelle, J. \& van Santen, R. A. Low temperature selective oxidation of ammonia to nitrogen on silver-based catalysts. Appl. Catal., B 40, 101-110 (2003).

5. Burch, R. \& Southward, B. W. L. The Nature of the Active Metal Surface of Catalysts for the Clean Combustion of Biogas Containing Ammonia. J. Catal. 198, 286-295 (2001).

6. Carabineiro, S. A. C., Matveev, A. V., Gorodetskii, V. V. \& Nieuwenhuys, B. E. Selective oxidation of ammonia over Ru(0 00 1). Surf. Sci. 555, 83-93 (2004).

7. Carabineiro, S. A. C. \& Nieuwenhuys, B. E. Selective oxidation

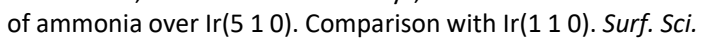
532-535, 87-95 (2003).

8. Qi, G., Gatt, J. E. \& Yang, R. T. Selective catalytic oxidation (SCO) of ammonia to nitrogen over Fe-exchanged zeolites prepared by sublimation of $\mathrm{FeCl} 3$. J. Catal. 226, 120-128 (2004).

9. Qi, G. \& Yang, R. T. Selective catalytic oxidation (SCO) of ammonia to nitrogen over Fe/ZSM-5 catalysts. Appl. Catal., A 287, 25-33 (2005).

10. Long, R. Q. \& Yang, R. T. Superior ion-exchanged ZSM-5 catalysts for selective catalytic oxidation of ammonia to nitrogen. Chem. Comm. 1651-1652 (2000).

11. Gang, L., van Grondelle, J., Anderson, B. G. \& van Santen, R. A. Selective Low Temperature NH3 Oxidation to $\mathrm{N} 2$ on Copper-Based Catalysts. J. Catal. 186, 100-109 (1999).

12. Chmielarz, L., Kuśtrowski, P., Rafalska-Łasocha, A. \& Dziembaj, R. Selective oxidation of ammonia to nitrogen on transition metal containing mixed metal oxides. Appl. Catal., $B$ 58, 235-244 (2005).

13. Lee, S. M. \& Hong, S. C. Promotional effect of vanadium on the selective catalytic oxidation of $\mathrm{NH} 3$ to $\mathrm{N} 2$ over Ce/V/TiO2 catalyst. Appl. Catal., B 163, 30-39 (2015).
14. Il'chenko, N. I. Catalytic Oxidation of Ammonia. Russ. Chem. Rev. 45, 1119 (1976).

15. Chmielarz, L. \& Jablonska, M. Advances in selective catalytic oxidation of ammonia to dinitrogen: a review. RSC Adv. 5, 43408-43431 (2015).

16. Barbier Jr, J., Oliviero, L., Renard, B. \& Duprez, D. Catalytic wet air oxidation of ammonia over $\mathrm{M} / \mathrm{CeO} 2$ catalysts in the treatment of nitrogen-containing pollutants. Catal. Today 75, 29-34 (2002).

17. Li, P., Zhang, R., Liu, N. \& Royer, S. Efficiency of Cu and Pd substitution in Fe-based perovskites to promote N2 formation during $\mathrm{NH} 3$ selective catalytic oxidation (NH3SCO). Appl. Catal., B 203, 174-188 (2017).

18. Lousteau, C., Besson, M. \& Descorme, C. Catalytic wet air oxidation of ammonia over supported noble metals. Catal. Today 241, Part A, 80-85 (2015).

19. Jabłońska, M. et al. Zeolite $Y$ modified with palladium as effective catalyst for selective catalytic oxidation of ammonia to nitrogen. J. Catal. 316, 36-46 (2014).

20. Li, Y. \& Armor, J. N. Selective NH3 oxidation to N2 in a wet stream. Appl. Catal. B., 13, 131-139 (1997).

21. Nilsson, J. et al. Chemistry of Supported Palladium Nanoparticles during Methane Oxidation. ACS Catal. 5, 2481-2489 (2015).

22. Tew, M. W., Janousch, M., Huthwelker, T. \& van Bokhoven, J. A. The roles of carbide and hydride in oxide-supported palladium nanoparticles for alkyne hydrogenation. J. Catal. 283, 45-54 (2011).

23. Khan, N. A., Shaikhutdinov, S. \& Freund, H. J. Acetylene and Ethylene Hydrogenation on Alumina Supported Pd-Ag Model Catalysts. Catal. Lett. 108, 159-164 (2006).

24. Tew, M. W., Nachtegaal, M., Janousch, M., Huthwelker, T. \& van Bokhoven, J. A. The irreversible formation of palladium carbide during hydrogenation of 1-pentyne over silicasupported palladium nanoparticles: in situ Pd K and L3 edge XAS. Phys. Chem. Chem. Phys. 14, 5761-5768 (2012).

25. Zhang, L., Zhang, C. \& He, H. The role of silver species on $\mathrm{Ag} / \mathrm{Al} 2 \mathrm{O} 3$ catalysts for the selective catalytic oxidation of ammonia to nitrogen. J. Catal. 261, 101-109 (2009).

26. Bugaev, A. L. et al. In situ formation of hydrides and carbides in palladium catalyst: When XANES is better than EXAFS and XRD. Catal. Today 283, 119-126 (2017).

27. Lin, C.-M et al. Size-dependent lattice structure of palladium studied by $\mathrm{x}$-ray absorption spectroscopy. Phys. Rev. B 75, 125426 (2007).

28. Beale, A. M. \& Weckhuysen, B. M. EXAFS as a tool to interrogate the size and shape of mono and bimetallic catalyst nanoparticles. Phys. Chem. Chem. Phys. 12, 55625574 (2010).

29. Soldatov, A. V., Della Longa, S. \& Bianconi, A. Relevant role of hydrogen atoms in the XANES of Pd hydride: Evidence of hydrogen induced unoccupied states. Solid State Commun. 85, 863-868 (1993).

30. Ruckman, M. W. et al. XANES study of hydrogen incorporation in a Pd-capped Nb thin film. Phys. Rev. B 57, 3881-3886 (1998).

31. Tew, M. W., Miller, J. T. \& van Bokhoven, J. A. Particle Size Effect of Hydride Formation and Surface Hydrogen Adsorption of Nanosized Palladium Catalysts: L3 Edge vs K Edge X-ray Absorption Spectroscopy. The J. Phys. Chem. C 113, 15140-15147 (2009).

32. Veith, G. M. et al. Evidence for the Formation of NitrogenRich Platinum and Palladium Nitride Nanoparticles. Chem. Mater. 25, 4936-4945 (2013).

33. D., B. Handbook of X-ray Spectroscopy C. D. Wanger, W. M. Riggs, L. E. Davis, J. F. Moulder and G. E. Muilenberg PerkinElmer Corp., Surface and Interface Analysis. 3, 190 (1981).

34. Rogers, S. M. et al. Tandem Site- and Size-Controlled Pd Nanoparticles for the Directed Hydrogenation of Furfural. ACS Catal. 7, 2266-2274 (2017). 
35. Wang, H. \& Agmon, N. Complete Assignment of the Infrared Spectrum of the Gas-Phase Protonated Ammonia Dimer. J. Phys. Chem. A 120, 3117-3135, (2016).

36. Liu, F. et al. Novel MnWOx catalyst with remarkable performance for low temperature NH3-SCR of NOx. Cat. Sci. Tech. 3, 2699-2707 (2013).

37. Zhang, L. \& He, H. Mechanism of selective catalytic oxidation of ammonia to nitrogen over Ag/Al2O3. J. Catal. 268, 18-25 (2009).

38. Amores, J. G., Escribano, V. S., Ramis, G. \& Busca, G. An FT-IR study of ammonia adsorption and oxidation over anatasesupported metal oxides. Appl. Catal., B 13, 45-58 (1997).

39. Carré, S., Dujardin, C. \& Granger, P. Operando infrared spectroscopy of the reduction of $\mathrm{NO}$ by $\mathrm{H} 2$ over rhodium based catalysts. Catal. Today, 191, 59-64 (2012).

40. Zhanpeisov, N. U. et al. Interaction of $\mathrm{N}_{2} \mathrm{O}$ with $\mathrm{Ag}^{+}$ionexchanged zeolites: an FT-IR spectroscopy and quantum chemical ab initio and DFT studies. J. Mol. Cat. A: Chemical 201, 237-246 (2003)

41. Wcław, A., Nowińska, K., Schwieger, W. \& Zielińska, A. N2O decomposition over iron modified zeolites ZSM-5. Catal. Today, 90, 21-25 (2004).

42. Zhang, X., He, H., Gao, H. \& Yu, Y. Experimental and theoretical studies of surface nitrate species on $\mathrm{Ag} / \mathrm{Al} 2 \mathrm{O} 3$ using DRIFTS and DFT. Spectrochim. Acta, Part A 71, 14461451 (2008).

43. Müslehiddinoğlu, J. \& Vannice, M. A. Adsorption of NO on promoted Ag/ $\alpha-\mathrm{Al} 2 \mathrm{O} 3$ catalysts. J. Catal. 217, 442-456 (2003).

44. Underwood, G. M., Miller, T. M. \& Grassian, V. H. Transmission FT-IR and Knudsen Cell Study of the Heterogeneous Reactivity of Gaseous Nitrogen Dioxide on Mineral Oxide Particles. J. Phys. Chem. A 103, 6184-6190 (1999).

45. Caravaggio, G., Nossova, L. \& Burich, R. Influence of Supports on Pd Catalysts for the Selective Catalytic Reduction of $\mathrm{NO}_{\mathrm{x}}$ with $\mathrm{H}_{2}$ and CO. Emission Control Science and Technology 2, 10-19 (2016).

46. Thompson, P. B. J. et al. X-ray spectroscopy for chemistry in the 2-4 keV energy regime at the XMaS beamline: ionic liquids, $\mathrm{Rh}$ and $\mathrm{Pd}$ catalysts in gas and liquid environments, and $\mathrm{Cl}$ contamination in [gamma]-Al2O3. J. Synchrotron Radiat. 22 (2015).

47. Gibson, E. K. et al. Restructuring of AuPd Nanoparticles Studied by a Combined XAFS/DRIFTS Approach. Chem. Mater. 27, 3714-3720 (2015).

48. Dann, E. K. et al. Combined In Situ XAFS/DRIFTS Studies of the Evolution of Nanoparticle Structures from Molecular Precursors. Chem. Mater. 29, 7515-7523 (2017).

49. Marinkovic, N. S. et al. Combined in situ X-ray absorption and diffuse reflectance infrared spectroscopy: An attractive tool for catalytic investigations. Nucl. Instrum. Methods Phys. Res., Sect. A 649, 204-206 (2011).

50. Kresse, G. \& Hafner, J. Ab initio molecular dynamics for liquid metals. Phys. Rev. B 47, 558-561 (1993).

51. Kresse, G. \& Hafner, J. Ab initio molecular-dynamics simulation of the liquid-metal-amorphous-semiconductor transition in germanium. Phys. Rev. B 49, 14251-14269 (1994).

52. Kresse, G. \& Furthmüller, J. Efficient iterative schemes for ab initio total-energy calculations using a plane-wave basis set. Phys. Rev. B 54, 11169-11186 (1996).

53. Blöchl, P. E. Projector augmented-wave method. Phys. Rev. B 50, 17953-17979 (1994).

54. Kresse G., Marsman M. and Furthmuller J., Vienna Ab Initio Simulation Package (VASP), Universität Wien, http://cms.mpi.univie.ac.at/vasp/guide/node124.html (2018).

55. Perdew, J. P., Burke, K. \& Ernzerhof, M. Generalized Gradient Approximation Made Simple. Phys. Rev. Lett. 77, 3865-3868 (1996).
56. Makov, G. \& Payne, M. Periodic boundary conditions in ab initio calculations. Phys. Rev. B 51, 4014-4022 (1995).

57. Neugebauer, J. \& Scheffler, M. Adsorbate-substrate and adsorbate-adsorbate interactions of $\mathrm{Na}$ and $\mathrm{K}$ adlayers on Al(111). Phys. Rev. B 46, 16067-16080 (1992).

58. Grimme, S., Antony, J., Ehrlich, S. \& Krieg, H. A consistent and accurate $a b$ initio parametrization of density functional dispersion correction (DFT-D) for the 94 elements H-Pu. J. Chem. Phys. 132, (2010).

59. Henkelman, G., Uberuaga, B. P. \& Jónsson, H. Climbing image nudged elastic band method for finding saddle points and minimum energy paths. J. Chem. Phys. 113, 9901-9904 (2000).

60. Henkelman, G. \& Jónsson, H. Improved tangent estimate in the nudged elastic band method for finding minimum energy paths and saddle points. J. Chem. Phys. 113, 99019904, (2000).

\section{Acknowledgements}

UCL and EPSRC are acknowledged for the iCASE studentship of E.K.D. The beamline scientists at Swiss Light Source and staff at Paul Scherrer Institut are acknowledged for provision of beamtime (proposal 20160396). The beamline scientists at XMaS, European Synchrotron Radiation Facility are acknowledged for provision of beamtime (experiment 28-011213). XMaS is a UK national facility supported by EPSRC, and staff at University of Warwick and University of Liverpool are recognised for their support in facilitating the beamtime. The $\mathrm{RCaH}$ are acknowledged for use of facilities and Johnson Matthey for providing catalyst precursor materials and testing facilities. UK Catalysis Hub is thanked for resources and support provided via our membership of the UK Catalysis Hub Consortium (portfolio grants EP/K014706/1, EP/K014668/1, $E P / K 014854 / 1, E P / K 014714 / 1$ and EP/I019693/1). Via our membership of the UK's HEC Materials Chemistry Consortium, which is funded by EPSRC (EP/L000202), this work used the ARCHER UK National Supercomputing service (http:www.archer.ac.uk). We acknowledge the use of Athena at HPC Midlands+, which was funded by the EPSRC on grant EP/P020232/1, in this research, via the EPSRC RAP call of spring 2018. We also thank HPC Wales for the computing time.

\section{Author Contributions}

The experiments on SuperXAS were performed by PPW, EKD, EKG, RHB, MN and AG. The experiments on XMAS at the ESRF were performed by PPW, EKD, GFT, PT, and SMR. The catalysts were prepared by EKD and $A R$, with routine characterisation performed by EKD. The XAS data was interpreted by PPW, EKD, $A K$ and EKG. XPS measurements were performed and analysed by EKD, SFRT, and TEE. The computational work was performed by $A C$ and CDZY. The work was conceived and designed by PPW, CRAC, AG, PC, and $\mathrm{CH}$. The manuscript was written by PPW, EKD, $A C$, and $A G$. 